\title{
Lamellar Bone is an Incremental Tissue Reconciling Enamel Rhythms, Body Size, and Organismal Life History
}

\author{
Timothy G. Bromage $\cdot$ Rodrigo S. Lacruz $\cdot$ Russell Hogg $\cdot$ Haviva M. Goldman • \\ Shannon C. McFarlin · Johanna Warshaw · Wendy Dirks · Alejandro Perez-Ochoa • \\ Igor Smolyar · Donald H. Enlow • Alan Boyde
}

Received: 16 September 2008/ Accepted: 18 January 2009/Published online: 21 February 2009

(C) The Author(s) 2009. This article is published with open access at Springerlink.com

\begin{abstract}
Mammalian enamel formation is periodic, including fluctuations attributable to the daily biological clock as well as longer-period oscillations that enigmatically correlate with body mass. Because the scaling of bone mass to body mass is an axiom of vertebrate hard tissue biology, we consider that long-period enamel formation rhythms may reflect corresponding and heretofore unrecognized rhythms in bone growth. The principal aim of this study is to seek a rhythm in bone growth demonstrably related to enamel oscillatory development. Our analytical approach is based in morphology, using a variety of hard tissue microscopy techniques. We first ascertain the relationship among long-
\end{abstract}

T. G. Bromage $(\square)$

Departments of Biomaterials and Biomimetics and Basic

Science and Craniofacial Biology, New York University College of Dentistry, 345 East 24th Street, New York, NY 10010, USA e-mail: tim.bromage@nyu.edu

\section{R. S. Lacruz}

Center for Craniofacial Molecular Biology, School of Dentistry, University of Southern California, Los Angeles, CA, USA

\section{R. S. Lacruz}

Institute for Human Evolution and BPI Palaeontology,

School of GeoSciences, University of the Witwatersrand,

Johannesburg, South Africa

R. Hogg

Department of Anthropology, The Graduate Center,

The City University of New York, New York, NY, USA

H. M. Goldman

Department of Neurobiology and Anatomy, Drexel University

College of Medicine, Philadelphia, PA, USA

S. C. McFarlin

Department of Anthropology, The George Washington

University, Washington, DC, USA period enamel rhythms, the striae of Retzius, and body mass using a large sample of mammalian taxa. In addition, we test whether osteocyte lacuna density (a surrogate for rates of cell proliferation) in bone is correlated with mammalian body mass. Finally, using fluorescently labeled developing bone tissues, we investigate whether the bone lamella, a fundamental microanatomical unit of bone, relates to rhythmic enamel growth increments. Our results confirm a positive correlation between long-period enamel rhythms and body mass and a negative correlation between osteocyte density and body mass. We also confirm that lamellar bone is an incremental tissue, one lamella formed in the species-

\author{
J. Warshaw \\ Department of Basic Science and Craniofacial Biology, \\ New York University College of Dentistry, New York, NY, USA \\ W. Dirks \\ School of Dental Sciences, Newcastle University, \\ Newcastle upon Tyne, UK \\ A. Perez-Ochoa \\ Centro Superior de Estudios Universitarios, \\ Lasalle University, Madrid, Spain \\ I. Smolyar \\ National Oceanographic Data Center, National Oceanic \\ and Atmospheric Administration, Silver Spring, MD, USA \\ D. H. Enlow \\ Case School of Dental Medicine, Case Western Reserve \\ University, Cleveland, OH, USA \\ A. Boyde \\ Dental Biophysics, Centre for Oral Growth and Development, \\ Queen Mary University of London, London, UK
}


specific time dependency of striae of Retzius formation. We conclude by contextualizing our morphological research with a current understanding of autonomic regulatory control of the skeleton and body mass, suggesting a central contribution to the coordination of organismal life history and body mass.

Keywords Bone lamella - Enamel striae of Retzius . Chronobiology $\cdot$ Life history

Biological rhythms exert considerable regulatory control over an organism's physiology, behavior, and development, which are particularly visible as daily metabolic fluctuations attributable to the central circadian clock [1]. Dental hard tissues (e.g., enamel and dentine) reflect these cycles, but also provide signatures of much longer periods (e.g., days to years), offering a unique window into the study of organismal life history. Bone, on the other hand, has not been recognized as a rhythmic tissue except for intermittent growth cycles commonly observed in seasonally growing animals [2].

Bone forming cells, the osteoblasts, secrete their organic matrix in discrete tissue patterns, which frequently include formation of the lamella, a fundamental microanatomical unit of bone observed in the postnatal tissues of many vertebrate taxa [3, 4]. The lamella is characterized in histological thin sections by a highly oriented band of collagen separated from adjacent bands by an interlamellar zone of less oriented collagen [5], resulting in the discrimination of one lamella from the next in polarized light. Lamellar bone is strikingly incremental in appearance, but the periodic formation of lamellae is the subject of only two preliminary reports $[6,7]$. In this early research a $24-\mathrm{h}$ rhythm was recorded for the formation of one lamella in three small mammals and a longer but uncertain rhythm in one larger mammal.

Mammalian teeth, on the other hand, are well documented to exhibit incremental structures representing successive forming fronts of enamel at varying time scales. Enamel forming cells, the ameloblasts, secrete their matrix with a circadian (ca. 24-h) periodicity, giving rise to daily increments referred to as cross striations, or alternating varicosities and constrictions, which are observed by a variety of microscopy techniques and widely used in studies of primate dental development and life history [8-10]. Enamel also exhibits a long-period increment called the stria of Retzius [11], which represents a temporary but profound periodic slowing of enamel formation in various multiples of whole days. The number of cross striations between striae is referred to as the repeat interval, which is identical for all teeth of an individual organism but is variable between and sometimes within species [12].
Cross striations are the result of daily variation in ameloblast secretory rate [10]. The etiology of striae of Retzius is unknown despite the exceedingly periodic nature of their expression. Equally enigmatic is the suggestion that the repeat interval scales with body size. Among primates it has been observed that smaller-bodied taxa have short repeat intervals while those of larger bodied primates are longer, suggesting a correlation between repeat interval and body size [13, 14], although no functional explanation for the scaling of striae of Retzius with body size has been asserted.

It is not unreasonable to assume that growth increments in bone would show a relationship with body size, insofar as the scaling of bone mass to body mass is an axiom of vertebrate hard tissue biology [15]. Because enamel and bone are each incrementally formed by cells secreting an organic matrix that is subsequently mineralized, we hypothesize that enamel tissue rhythms will have a correspondence with the incremental growth of lamellar bone, and that this association should be reflected during bone growth and bone remodeling processes that relate to an organism's body mass.

To test this hypothesis, we investigate 'ground' sections of the bones and teeth of a large sample of mammalian taxa, using a variety of analytical microscopy techniques. In three steps we aim (i) to further validate a relationship between striae repeat interval and body mass across many mammalian taxa, including fossil hominins (extinct human ancestors); (ii) to determine whether mammalian osteocyte density - a surrogate for inferring rates of bone growth and remodeling - is related to body mass across various Primate and non-Primate taxa; and (iii) having independently established relationships between both stria repeat interval and bone formation rates with body mass, to logically extend the argument and establish if there is a relation between the enamel striae of Retzius and the formation rate of bone lamellae.

Finally, we also aim to contextualize our results with a literature on the central autonomic regulation of bone/body mass, thus reconciling our investigation of long-period rhythms with skeletal development and organismal life history research. This step, while speculative, is important for directing the focus of future experimental research onto physiological pathways implicated in the control of longperiod rhythms.

\section{Materials and Methods}

\section{Specimens}

To support and expand earlier research on the relation between striae of Retzius repeat interval and body mass, tooth samples from 42 modern and fossil species/ 
Table 1 Primate striae of Retzius repeat interval (RI) and body mass

\begin{tabular}{|c|c|c|c|c|c|}
\hline Genus & Species & Sex & $\begin{array}{l}\text { Striae of } \\
\text { Retzius RI }\end{array}$ & Body mass $(\mathrm{kg})^{\mathrm{a}}$ & $\begin{array}{l}\text { Specimen source } \\
\text { or RI ref. no. }\end{array}$ \\
\hline \multicolumn{6}{|c|}{ Infraorder Platyrrhini } \\
\hline Alouatta & sp. & M & 6 & 5.99 & MNRJ \\
\hline Aotus & sp. & $\mathrm{F}$ & 3 & 0.772 & $\mathrm{CSHO}$ \\
\hline Callimico & goeldii & $\mathrm{F}$ & 3 & 0.463 & Rose \\
\hline Callithrix & humeralifer & $\mathrm{F}$ & 3 & 0.35 & $\mathrm{AMNH}$ \\
\hline Callithrix & jacchus & $?$ & 1 & 0.32 & $\mathrm{AMNH}$ \\
\hline Cebuella & pygmaea & $\mathrm{F}$ & 1 & 0.122 & MNRJ \\
\hline Cebus & albifrons & M & 6 & 3.18 & $\mathrm{AMNH}$ \\
\hline Cebus & albifrons & $\mathrm{F}$ & 5 & 2.29 & $\mathrm{AMNH}$ \\
\hline Cebus & paella & $\mathrm{M}$ & 5 & 3.65 & AMNH \\
\hline Cebus & paella & $\mathrm{F}$ & 4 & 2.52 & $\mathrm{CSHO}$ \\
\hline Cebus & capucinus & $\mathrm{F}$ & 4 & 2.54 & NMNH \\
\hline Cebus & capucinus & $\mathrm{M}$ & 6 & 3.68 & Rose \\
\hline Cebus & olivaceus & M & 4 & 3.29 & $\mathrm{AMNH}$ \\
\hline Cebus & capucinus & $\mathrm{M}$ & 6 & 3.68 & AMNH \\
\hline Leontopithecus & rosalia & $?$ & 3 & 0.6 & $\mathrm{AMNH}$ \\
\hline Saguinus & oedipus & $\mathrm{F}$ & 1 & 0.404 & NMNH \\
\hline Saguinus & nigricollis & $\mathrm{F}$ & 2 & 0.45 & $\mathrm{NMNH}$ \\
\hline Saguinus & fuscicollis & $?$ & 2 & 0.343 & $\mathrm{AMNH}$ \\
\hline Saimiri & boliviensis & $\mathrm{F}$ & 3 & 0.711 & AMNH \\
\hline Saimiri & sciureus & M & 3 & 0.779 & AMNH \\
\hline Saimiri & oerstedii & M & 3 & 0.897 & $\mathrm{AMNH}$ \\
\hline \multicolumn{6}{|c|}{ Infraorder Catarrhini } \\
\hline Afropithecus ${ }^{\mathrm{b}}$ & turkanensis & $?$ & 8 & $34.5[54]$ & [55] \\
\hline Dryopithecus $^{\mathrm{b}}$ & laietanus & $?$ & 7 & $23[56]$ & [57] \\
\hline Erythrocebus & patas & $\mathrm{F}$ & 4 & 4.8 & CNAR $^{\mathrm{c}}$ \\
\hline Gigantopithecus $^{\mathrm{b}}$ & blacki & $?$ & 11 & $300[58]$ & [58] \\
\hline Gorilla & gorilla & $\mathrm{F}$ & $9^{a}$ & 75.7 & [59] \\
\hline Gorilla & gorilla & M & $10^{\mathrm{a}}$ & 169.3 & [59] \\
\hline Graecopithecus $^{\mathrm{b}}$ & freybergi & M & 8 & $63[56]$ & {$[60]$} \\
\hline Homo & sapiens & $\mathrm{F}$ & $8^{a}$ & 53.6 & [59] \\
\hline Homo & sapiens & M & $8^{a}$ & 60.2 & [59] \\
\hline Hylobates & lar & $?$ & 4 & 5.6 & {$[61,62]$} \\
\hline Hylobates & syndactylus & $\mathrm{F}$ & 4.5 & 10.7 & [61] \\
\hline Macaca & nemestrina & $\mathrm{F}$ & 4 & 7.8 & {$[8]$} \\
\hline Pan & troglodytes & $\mathrm{F}$ & 6 & 31.1 & {$[63]$} \\
\hline Pan & troglodytes & M & 6 & 40.5 & [63] \\
\hline Papio & hamadryas hamadryas & $\mathrm{F}$ & 7 & 9.4 & {$[64]$} \\
\hline Papio & hamadryas anubis & M & 7 & 21 & {$[64]$} \\
\hline Pongo & pygmaeus & $\mathrm{F}$ & $10^{\mathrm{a}}$ & 35.8 & {$[65]$} \\
\hline Pongo & pygmaeus & $\mathrm{M}$ & $10^{\mathrm{a}}$ & 78.3 & {$[65]$} \\
\hline Proconsul $^{\mathrm{b}}$ & nyanzae & $?$ & 6 & $35[66]$ & {$[66]$} \\
\hline Proconsul $^{\mathrm{b}}$ & heseloni & $?$ & 5 & $10.5[67]$ & {$[66]$} \\
\hline Semnopithecus & entellus priam & $\mathrm{F}$ & 5 & 9.9 & {$[61]$} \\
\hline Theropithecus & gelada & $\mathrm{F}$ & 7 & 13.6 & {$[68]$} \\
\hline Theropithecus & gelada & M & 7 & 20.5 & {$[68]$} \\
\hline \multicolumn{6}{|c|}{ Suborder Strepsirhini } \\
\hline Megaladapis $^{\mathrm{b}}$ & edwardsi & $?$ & 3 & 88 [69] & [70] \\
\hline
\end{tabular}


Table 1 continued

\begin{tabular}{llllll}
\hline Genus & Species & Sex & $\begin{array}{l}\text { Striae of } \\
\text { Retzius RI }\end{array}$ & Body mass (kg) $^{\text {a }}$ & $\begin{array}{l}\text { Specimen source } \\
\text { or RI ref. no. }\end{array}$ \\
\hline $\begin{array}{lllll}\text { Nycticebus } \\
\text { Paleopropithecus }^{\mathrm{b}}\end{array}$ & sp. & $?$ & 2 & 0.679 & Rosenberger \\
\hline
\end{tabular}

AMNH American Museum of Natural History, CNAR Comparative Neurobiology of Aging Resource, CSHO Center for the Study of Human Origins, New York University, HTRU Hard Tissue Research Unit, NYU College of Dentistry, MNRJ Museo Nacional do Rio de Janeiro, NMNH National Museum of Natural History; Rose, Rose Primate Collection, Queensborough Community College, New York; Rosenberger, private collection of Dr. Alfred Rosenberger, Brooklyn College

a The number of daily cross striations between striae of Retzius is referred to as the RI. RI values are derived from the analysis of one individual except that, for some taxa, larger samples were investigated and mode (central tendency) values are indicated. Body mass estimates are taken from the literature except where indicated $[39,71]$

b Fossil taxon

${ }^{c}$ Patas monkey specimens were kindly made available to the current study by Drs. Joseph M. Erwin and Patrick R. Hof, and were supported by the Comparative Neurobiology of Aging Resource (NIH AG14308)

subspecies of the order Primates, representing the infraorders Platyrrhini and Catarrhini and the suborder Strepsirhini are investigated (Table 1). This relationship is as well examined in a compilation of striae of Retzius repeat intervals and body masses for 11 extinct and living members of the human lineage (Table 2). To determine whether this relationship might also be extended to another and disparate mammalian taxon, seven members of the order Proboscidea were investigated (Table 3).

With respect to the relationship between osteocyte density and body mass, measurements were made on eight primates representing the infraorder Catarrhini and the suborder Strepsirhini and three nonprimate mammals (Table 4). Measurements for human were represented by five individual females aged 38-62 from people of known life history.

To investigate striae of Retzius repeat intervals and their relationships with lamellar formation rates, we acquired the vitally labeled immature bone of five mammals for which the times of administration of the labels were known. Table 5 provides labeling schedules for rat [16], macaque [17], patas monkey (this study), sheep [18], and human (inferred) (see published sources for details of the labeling protocols). Teeth were obtained from the same species/variety or, in the case of the patas monkey, from the same individual.

\section{Sample Preparation}

All modern bone and tooth samples directly investigated by us were cleaned of nonmineralized organic components with daily changes of fresh $1 \%$ Terg-a-Zyme (Alconox, NY) aqueous enzyme solution at $50^{\circ} \mathrm{C}$ until clean [19]. Following this, samples were subject to graded ethanol substitution and then 50:50 isopropanol:heptane reflux in a Soxhlet apparatus for 7 to 14 days.

Upon removal from the Soxhlet apparatus, all modern and fossil samples, excepting early hominin specimens, were transferred and subject to polymethylmethacrylate
(PMMA) substitution and embedding. Each cured block was sawn through midshaft with a Buehler (Lake Bluff, IL) Isomet low-speed saw, hand ground through graded carbide papers to 1200 grit on a Buehler Handimet II, mounted on a glass slide, and sectioned, and the section was polished on a Buehler Ecomet III with a $1-\mu \mathrm{m}$ diamond suspension until a uniform thickness of $100 \pm 4 \mu \mathrm{m}$ was achieved, in most cases according to a published protocol [20].

Histological sections were typically prepared to a section thickness standard of $100 \pm 4 \mu \mathrm{m}$. All $\pm 4-\mu \mathrm{m}$ section thickness monitoring was determined using an Edge R400 3D Transmitted Light Microscope [21, 22] (Edge R400: Micro Science Technologies, Marina del Ray, CA) fitted with calibrated $1 / 10-\mu \mathrm{m}$ staging in the $\mathrm{Z}$ direction and using a Nikon PlanApo 40/0.95 objective lens.

No early hominin specimen examined for this research was sectioned, these being examined by confocal microscopy (see Microscopy and Analysis below), thus requiring no preparation.

\section{Microscopy and Analysis}

\section{Striae of Retzius and lamellae}

Histological 'ground' thin sections were coverslipped with ethylene glycol and imaged in conventional transmitted light (LM) and circularly polarized transmitted light (CPL) using a Leica-Leitz DMRX/E Universal Microscope configured with a Marzhauser motorized stage and CPL filters and using Leica PL Fluotar 40/0.70 (enamel) and PL Fluotar 20/0.50 (lamellae) objective lenses. LM and CPL images were acquired with a JVC KYF55B color videocamera using Syncroscopy Montage Explorer software (Synoptics Inc., Frederick, MD).

Evaluations of the number of daily increments between adjacent striae of Retzius, or the repeat interval, were performed on images compiled into large $\mathrm{XY}$ montages 
Table 2 Hominin striae of Retzius repeat interval (RI) and body mass

\begin{tabular}{|c|c|c|c|c|c|}
\hline Specimen & Genus & Species & Striae of Retzius RI & Body mass $(\mathrm{kg})^{\mathrm{a}}$ & $\begin{array}{l}\text { Specimen source } \\
\text { or RI ref. no. }\end{array}$ \\
\hline NM-ER- 30749 & Australopithecus & Anamensis & 7 & $51-33$ & {$[72]$} \\
\hline KNM-ER- 30748 & Australopithecus & Anamensis & 7 & $51-33$ & {$[72]$} \\
\hline Mean & & & 7 & 42 & \\
\hline AL- 333-52 & Australopithecus & Afarensis & 7 & $45-29$ & NME \\
\hline AL- 366-1 & Australopithecus & Afarensis & 7 & $45-29$ & NME \\
\hline L-2-79 (OMO) & Australopithecus & Afarensis & 7 & $45-29$ & NME \\
\hline Mean & & & 7 & 37 & \\
\hline Stw 11 & Australopithecus & Africanus & 7 & $41-30$ & UWMS \\
\hline Stw 40 & Australopithecus & Afarensis & 6,7 & $45-29$ & UWMS \\
\hline Stw 90 & Australopithecus & Africanus & 7 & $41-30$ & UWMS \\
\hline Stw 188 & Australopithecus & Africanus & 6 & $41-30$ & UWMS \\
\hline Stw 267 & Australopithecus & Africanus & 9 & $41-30$ & UWMS \\
\hline Stw 284 & Australopithecus & Africanus & 7 & $41-30$ & UWMS \\
\hline Stw 285 & Australopithecus & Africanus & 7 & $41-30$ & UWMS \\
\hline Stw $252 \mathrm{k}$ & Australopithecus & Africanus & 8 & $41-30$ & UWMS \\
\hline Mean & & & 7.2 & 35.5 & \\
\hline$F-22-1 b$ & Paranthropus & Aethiopicus & 7 & $49-34$ & NME \\
\hline L 209-17 & Paranthropus & Boisei & 7 & $49-34$ & NME \\
\hline L-398-847 & Paranthropus & Boisei & 7 & $49-34$ & NME \\
\hline OMO 47-46 & Paranthropus & Boisei & 7 & $49-34$ & NME \\
\hline OMO 76-37 & Paranthropus & Boisei & 7 & $49-34$ & NME \\
\hline OMO 136-1 & Paranthropus & Boisei & 7 & $49-34$ & NME \\
\hline Mean & & & 7 & 41.5 & \\
\hline EM 2368 & Paranthropus & Robustus & 8 & $40-32$ & [73] \\
\hline SK 4771 & Paranthropus & Robustus & 7 & $40-32$ & NFI \\
\hline SK 4769 & Paranthropus & Robustus & 8 & $40-32$ & NFI \\
\hline SK 875 & Paranthropus & Robustus & 6 & $40-32$ & NFI \\
\hline SK 1524 & Paranthropus & Robustus & 7 & $40-32$ & NFI \\
\hline SKW 35 & Paranthropus & Robustus & 6 & $40-32$ & NFI \\
\hline SKW 37 & Paranthropus & Robustus & 7 & $40-32$ & NFI \\
\hline SKX 21841 & Paranthropus & Robustus & 6 & $40-32$ & NFI \\
\hline Mean & & & 6.9 & 36 & \\
\hline KNM-ER- 1482 & Ното & Rudolfensis & 7 & & NMK \\
\hline KNM-ER- 1802 & Ното & Rudolfensis & 8 & $60-51$ & NMK \\
\hline UR- 501 & Homo & Rudolfensis & 8 & & MDA \\
\hline Mean & & & 7.7 & 55.5 & \\
\hline KNM-ER-809 & Ното & Erectus & 8 & & NMK \\
\hline KNM-ER-3733 & Ното & Ergaster & 9 & $66-56$ & NMK \\
\hline S7-37 & Homo & Erectus & 7 & & FS \\
\hline \multirow[t]{2}{*}{ Mean } & & & 8 & 61 & \\
\hline & Ното & Sapiens & & $58-49$ & \\
\hline Mean & & & 8.3 & 53.5 & [74] \\
\hline
\end{tabular}

The number of daily cross striations between striae of Retzius is referred to as the RI

FS Forschungsinstitut, Senckenberg, NFI Northern Flagship Institution (formerly Transvaal Museum), NME National Museum of Ethiopia, NMK National Museum of Kenya, MDA Malawi Department of Antiquities, UWMS University of the Witwatersrand, Medical School. Specimens reported in Refs. [23] and [77] unless noted otherwise

${ }^{a}$ Body mass estimates from McHenry [75, 76] 
Table 3 Proboscidean striae of Retzius repeat interval (RI) and body mass

\begin{tabular}{lllll}
\hline Genus & Species & Striae of Retzius RI & Body mass (kg) & $\begin{array}{l}\text { Specimen source } \\
\text { or RI ref. no. }\end{array}$ \\
\hline Elephas $^{\mathrm{a}}$ & cypriotes & 6 & 200 [78] & TRNC \\
Elephas $^{\mathrm{a}}$ & recki & 14 & $7559.75[79]$ & MDA \\
Elephas $^{\mathrm{a}}$ & antiquus & 12 & $8752.55[79]$ & AMNH \\
Elephas $^{\text {Mammut }}$ & maximus & 14 & $3903[79]$ & [80] \\
Mammuthus $^{\mathrm{a}}$ & americanum & 14 & $7443[81]$ & [82] \\
Mammuthus $^{\mathrm{a}}$ & columbi & 14 & $7368.00[81]$ & MSHSSD \\
\hline
\end{tabular}

The number of daily cross striations between striae of Retzius is referred to as the RI

AMNH American Museum of Natural History, HTRU Hard Tissue Research Unit, NYU College of Dentistry, MDA Malawi Department of Antiquities, MNRJ Museo Nacional do Rio de Janeiro, MSHSSD Mammoth Site of Hot Springs, South Dakota, TRNC Turkish Republic of Northern Cyprus, Department of Antiquities. Repeat interval references pertain to analyses of dentine, in which long-period (Andresen lines) and circadian (von Ebner's lines) growth increments also occur and correspond to the striae of Retzius and cross striations in enamel, respectively $[84,85]$

${ }^{a}$ Fossil taxon

Table 4 Selected primate and nonprimate mammal osteocyte density and body mass

\begin{tabular}{|c|c|c|c|c|c|c|}
\hline $\begin{array}{l}\text { Specimen and common } \\
\text { name }\end{array}$ & Genus & Species & Age and gender ${ }^{\mathrm{a}}$ & $\begin{array}{l}\text { Osteocyte } \\
\text { density }\end{array}$ & $\begin{array}{l}\text { Body mass } \\
(\mathrm{kg})^{\mathrm{a}}\end{array}$ & $\begin{array}{l}\text { Specimen } \\
\text { source }\end{array}$ \\
\hline \multicolumn{7}{|c|}{ Primates Infraorder Catarrhini } \\
\hline Vervet & Chlorocebus & aethiops & Adult Female & 32,012 & 3.515 & UCSC \\
\hline Macaque & Macaca & mulatta & 4.16 yr Female & 22,222 & 3.0 & MIBP \\
\hline Chimpanzee & Pan & troglodytes & $\begin{array}{l}\text { M2 erupted (ca. } 6 \text { yr) } \\
\text { Female }\end{array}$ & 18,706 & $33.7[71]$ & $\mathrm{MNH}$ \\
\hline "Lucy" & Australopithecus ${ }^{\mathrm{b}}$ & afarensis & Adult Female & 23,333 & $27.5[86]$ & NME \\
\hline Human $^{c}$ & Homo & sapiens & $38-62$ yr Female & 20,444 & 62.4 & MFC \\
\hline \multicolumn{7}{|l|}{ Suborder Strepsirhini } \\
\hline Lesser galago & Galago & moholi & Adult & 51,724 & 0.244 & DUPC \\
\hline Greater galago & Cheirogales & major & Adult & 31,526 & 0.4 & DUPC \\
\hline Dwarf lemur & Otolemur & crassicaudatus & Adult & 44,353 & 1.15 & DUPC \\
\hline \multicolumn{7}{|l|}{ Nonprimate mammal } \\
\hline Rat (Wistar) & Rattus & norvegicus & 3 mo Female & 58,148 & 0.3 & HTRU \\
\hline Pygmy hippo & Phanourios $^{\mathrm{b}}$ & minutus & Adult & 23,641 & $200[87]$ & TRNC \\
\hline Hippo & Hipроротатиs & amphibius & Adult & 16,667 & $2000[88]$ & HLD \\
\hline
\end{tabular}

DUPC Duke University Primate Center, HLD Hessisches Landesmuseum Darmstadt, HTRU Hard Tissue Research Unit, NYUCD, MFC Melbourne Femur Collection, Melbourne, Australia, MIBP Morgan Island Breeding Program, Yemassee, South Carolina, MNH Museum für Naturkunde der Humboldt Universität, NME National Museum of Ethiopia, TRNC Turkish Republic of Northern Cyprus, Department of Antiquities, UCSC Sherwood L. Washburn collection, University of California at Santa Cruz

${ }^{a}$ Age and sex are given when known. No adult specimen was geriatric. Body mass was measured directly from study individuals except where indicated by citation

${ }^{\mathrm{b}}$ Fossil taxon

c The MFC sample consists of five human females aged 38, 42, 49, 55, and 62 (average $=62.4$ ), whose osteocyte densities measured 18,333, $22,222,20,741,20,000$, and 20,926 respectively (average $=2044 ; \mathrm{SD}=1426$ ). Statistics of the relationship between osteocyte lacuna density and body mass are given in Fig. 4

using an automated Montage Explorer capture. In addition, averages of cross-striation widths in micrometers were divided into averages of the distance between striae of Retzius for two regions of the same tooth. This allowed a second estimate of the repeat interval; a value was recorded only when both sets of numbers agreed.
For vitally labeled bone, fluorescence microscopy (FM) was also performed on the same LM and CPL fields of view. When fluorescence was weak or diffuse, FM was performed with a Perkin Elmer (Waltham, MA) UltraView ERS 3E situated on an AxioImager M1 Zeiss microscope (Carl Zeiss MicroImaging, Inc.) and using a Zeiss LD Plan- 
Table 5 Striae of Retzius repeat interval (RI) and lamellar formation rate

\begin{tabular}{|c|c|c|c|c|c|c|}
\hline $\begin{array}{l}\text { Specimen and common } \\
\text { name) }\end{array}$ & Genus & Species & Labeling protocol $^{\mathrm{a}}$ & $\begin{array}{l}\text { Striae of } \\
\text { Retzius RI }\end{array}$ & $\begin{array}{l}\text { Lamellar formation } \\
\text { rate/RI }\end{array}$ & $\begin{array}{l}\text { Specimen } \\
\text { source }\end{array}$ \\
\hline Rat (Wistar) & Rattus & norvegicus & $\mathrm{L}+7 \mathrm{~L}+4 \mathrm{~L}+11 \mathrm{~L}+9 \mathrm{E}$ & 1 & 1 & HTRU \\
\hline Macaque & Macaca & nemestrina & $\mathrm{L}+14 \mathrm{~L}+14 \mathrm{~L}+18 \mathrm{E}$ & 4 & 1 & SBDA \\
\hline Patas monkey & Erythrocebus & patas & $\mathrm{L}+3 \mathrm{~L}+3 \mathrm{~L}+3 \mathrm{E}$ & 4 & 1 & $\mathrm{CNAR}^{\mathrm{b}}$ \\
\hline Sheep (Warhill) & Ovis & aries & $\mathrm{L}+11 \mathrm{~L}+$ hiatus $+\mathrm{L}+11 \mathrm{~L}$ & 5 & 1 & $\begin{array}{l}\text { CSU \& } \\
\text { UCDMC }\end{array}$ \\
\hline $\begin{array}{l}\text { Human (circumstantial } \\
\text { evidence) }\end{array}$ & Homo & sapiens & $\begin{array}{l}\text { Multiple presumed treatment } \\
\text { courses }\end{array}$ & 8 (from Table 1$)$ & 1 & MFC \\
\hline
\end{tabular}

The number of daily cross striations between striae of Retzius is referred to as the RI. Lamellar formation rate/RI refers to the number of lamellae formed per RI

CNAR Comparative Neurobiology of Aging Resource, CSU Colorado State University, Department of Clinical Sciences, HTRU Hard Tissue Research Unit, NYUCD, MFC Melbourne Femur Collection, Melbourne, Australia, SBDA State University of New York at Buffalo, Department of Anthropology, UCDMC University of California, Davis, Medical Center

${ }^{a}$ Number of days between administration of vital labels (L) and euthanization (E) (see published sources for labeling protocol details): rat [16], macaque [17], patas monkey (this study; oral dose of $10 \mathrm{mg} / \mathrm{kg}$ tetracycline), sheep [18], and human

${ }^{\mathrm{b}}$ Patas monkey specimens were labeled and kindly made available to the current study by Drs. Joseph M. Erwin and Patrick R. Hof, and were supported by the Comparative Neurobiology of Aging Resource (NIH AG14308)

Neofluor 40/0.60 objective lens. The 488- and 568-nm laser lines were used to excite vital labels. Automated $Z$-axis image capture on the Axiovert was performed with a piezoz-stepper. Images were acquired with a cooled 12-bit CCD Orca ER camera at magnifications and fields of view matching Leitz DMRX/E images. Digital image overlays between DMRX/E CPL and UltraView ERS 3E FM images were performed using crop, rotation, and screen functions in Adobe Photoshop CS2 (San Jose, CA).

Early hominin images of enamel and bone were obtained by Portable Confocal Scanning Optical Microscopy (PCSOM) [23], employing a Technical Instrument Co. K2S-BIO confocal module (Zygo Corp., Sunnyvale, CA) with conventional white light, a Mitutoyo M Plan Apo 20/0.42 objective lens, and a JVC KYF1030 camera. Using Montage Explorer software we obtained high-resolution images of early hominin internal structures, such as cross striations and striae of Retzius from naturally occurring occlusocervical fractures in enamel, and lamellae from intact and fractured bones.

To demonstrate that lamellae develop incrementally, when specimens allowed (human and sheep) we imaged both primary and secondarily remodeled lamellar bone by FM.

\section{Osteocyte Density}

All imaging, excepting that of the early hominin specimen, was performed with the Edge R400 as described above, configured to provide transmitted oblique circularly polarized light contrast as useful. Sections were coverslipped with ethylene glycol, and XY fields of view conforming to a $270-\mu \mathrm{m}$ field width by $200-\mu \mathrm{m}$ field height, respectively, and containing no dehydration cracks or vascular canals, were located. The periosteal cortex was imaged in all individuals, including, for purposes of control, specifically the lateral periosteal cortex from five modern humans, the average of which is given in Table 4.

An XY field of view selected, the focal plane was situated at the top surface of the section and then lowered in the $Z$-axis by a virtual translation of ca. $5 \mu \mathrm{m}$ through the section. The through series of images from each ca. 5- $\mu \mathrm{m}$ virtual focal plane was acquired using a JVC KYF75U camera and Syncroscopy Automontage (Synoptics Inc., Frederick, MD) until the final in-focus bottom surface image plane had been reached. A red-green anaglyph image with 20-deg angular separation was constructed from each through series with Automontage.

Each through series was presented for analysis on a PC configured with dual monitors. The Automontage through series was placed on one monitor, while the analglyph image was opened separately in Adobe Photoshop CS2 (San Jose, CA) on the other; the anaglyph was scaled to the same screen size as the Automontage source images. This side-by-side arrangement allowed the viewing of lacunae with red-green anaglyph glasses through the full 3D thickness of the histological section while also scrolling through and cross-checking source image details in Automontage. All lacunae were counted for each XYZ volume according to standard stereological procedure; those intersecting each of one $\mathrm{X}, \mathrm{Y}$, and $\mathrm{Z}$ surface were excluded, while those intersecting their contralateral $\mathrm{X}, \mathrm{Y}$, and $\mathrm{Z}$ surfaces were included. After all lacunae had been labeled, they were manually counted. For reasons mentioned in the Results, no attempt was made to subtract from the total count those lacunae whose cells may have been apoptotic. 
All measurements were standardized by extrapolation of the number of lacunae per measured bone volume, typically from a $5,400,000-\mu \mathrm{m}$ cubic measurement volume to a $1-\mathrm{mm}^{3}$ unit value.

Because of satisfactory image contrast obtained with the Edge R400, we are only rarely unsure about the existence of a lacuna. This was verified by intraobserver reinspection and recounting of five fields of view, in which error was limited to $1 \%$. Interobserver error remained below $5 \%$, most of the differences between observers being attributable to the detection of top and bottom surface intersecting lacunae.

Measurement of the early hominin was obtained by the PCSOM as described above [23]. In this case, a $270-\mu \mathrm{m}$ field width by $200-\mu \mathrm{m}$ field height field of view was imaged through $50 \mu \mathrm{m}$ from below the first surface.

\section{Enumerating Lamellae}

Bone lamellae in histological thin section appear as microanatomical lineations, but frequently they are domains laid down in patches, superficial to but not strictly overlapping the other, conforming to the three-dimensional shape of the forming front, which itself may not be flat [24]. Lamellae are thus typically anisotropic in two dimensions, appearing and disappearing across the field of view. This anisotropy may pose difficulties for the objective determination of what lineation is or is not a lamella to be counted. For this reason, novel methods for the study of incremental growth rate variability have been developed [25]. In the present study, fields of view containing contiguous lamellae were sought and evaluated; ambiguities associated with the visualization of lamellae are presented in the Discussion.

There are other methodological caveats that must be considered when enumerating lamellae with respect to developmental time. Instances of growth reversal due to cortical drift and transient growth cessation in the bones of seasonally growing animals are two examples of contiguous lamellae not representing continuous growth. In these cases, the micromorphology of a previously resorbed surface and/or a cement line typically demarcates the interruption of growth. While any numbers of observed lamellae have temporal meaning, to use lamellae for representations of continuous time, one must have reason to expect that their development was uninterrupted.

\section{Results}

Striae of Retzius Repeat Interval Correlates with Body Mass

The relationship between striae of Retzius and body mass in a range of living and fossil ape taxa has been recently explored [13]. We broaden and focus our examination of this relationship using a large sample of 23 New World primates of the infraorder Platyrrhini (Table 1). Repeat intervals obtained on platyrrhines, together with published data on other primates of the infraorder Catarrhini and suborder Strepsirhini, were regressed against the $\log$ of body mass estimates and show a statistically high relationship described by $r=0.79, p<0.01, r^{2}=0.62$, $y=3.136+1.04 * x$ (Fig. 1, Table 1). Employing data from the most comprehensive study and compilation of Plio-Pleistocene hominin repeat intervals to date [26], we also tested this relationship for early hominins, which are found to have repeat intervals ranging from 6 to 9 and which do indeed significantly correlate with estimated body mass and described by the relationship $r=0.87$, $p<0.01, r^{2}=0.75, y=5.262+0.0470 * x$ (Fig. 2, Table 2). To further test the broader applicability of this relationship in mammals, we examined living and extinct and macrofaunal and insular dwarfs of the order Proboscidea, which also reveal a significant correlation between body mass and striae of Retzius repeat interval described by $r=0.79, p=0.03, r^{2}=0.62, y=5.649+2.098 * x$ (Fig. 3, Table 3). When all primates and proboscideans examined here are treated together, the relationship is described by $r=0.87, p<0.01, r^{2}=0.75, y=3.078+$ $1.057 * x$.

\section{Osteocyte Lacuna Density Correlates with Body Mass}

Using the novel three-dimensional tallying method described under Materials and Methods, we compared

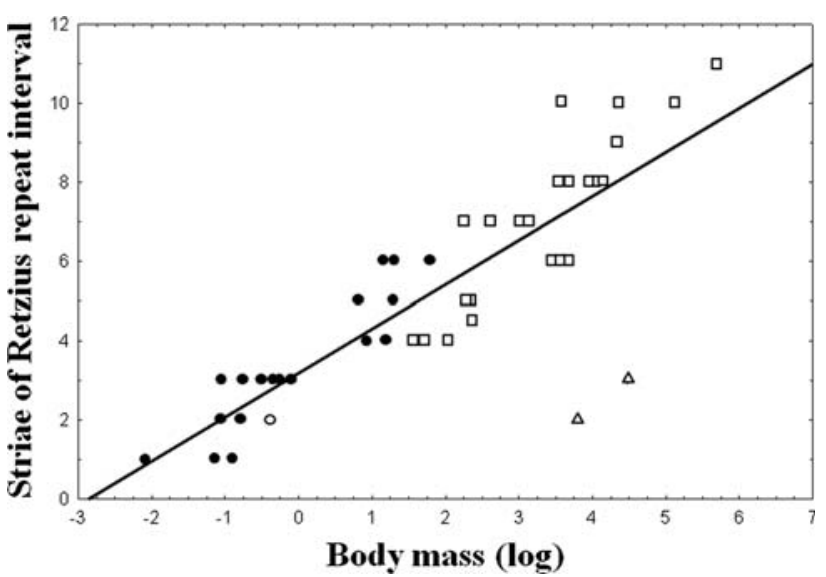

Fig. 1 Striae of Retzius repeat interval (RI) linearly regressed against log body mass for primates: $(\mathbf{O})$ platyrrhine; $(\square)$ catarrhine; $(\bigcirc, \Delta)$ strepsirrhine primates (least squares model). The number of daily cross striations between striae of Retzius is referred to as the RI. Raw data provided in Table 1 . Summary statistics for primates combined are as follows: $r=0.79, p<0.01, r^{2}=0.62, y=3.136+1.04 * x$. For platyrrhines, $r=0.92, p<0.01, r^{2}=0.85, y=3.451+1.416 *$ $x$. For catarrhines, $r=0.88, p<0.01, r^{2}=0.77, y=1.381+1.708$ $* x$. The $X$-axis represents the log of body mass measured in kilograms 


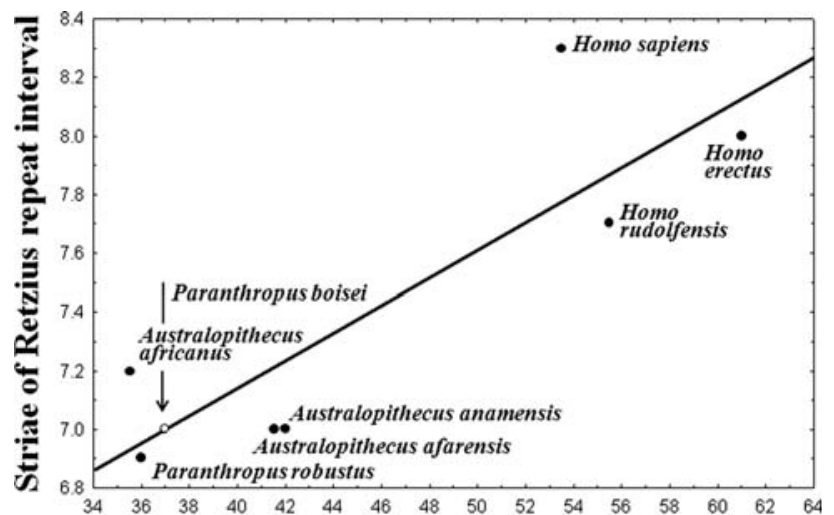

Body mass

Fig. 2 Average striae of Retzius repeat interval (RI) linearly regressed against log body mass for humans and their fossil ancestors (least squares model). The number of daily cross striations between striae of Retzius is referred to as the RI. Raw data are provided in Table 2. Summary statistics are as follows: $r=0.87, p<0.01$, $r^{2}=0.75, y=5.262+0.0470 * x$. The $X$-axis represents body mass measured in kilograms

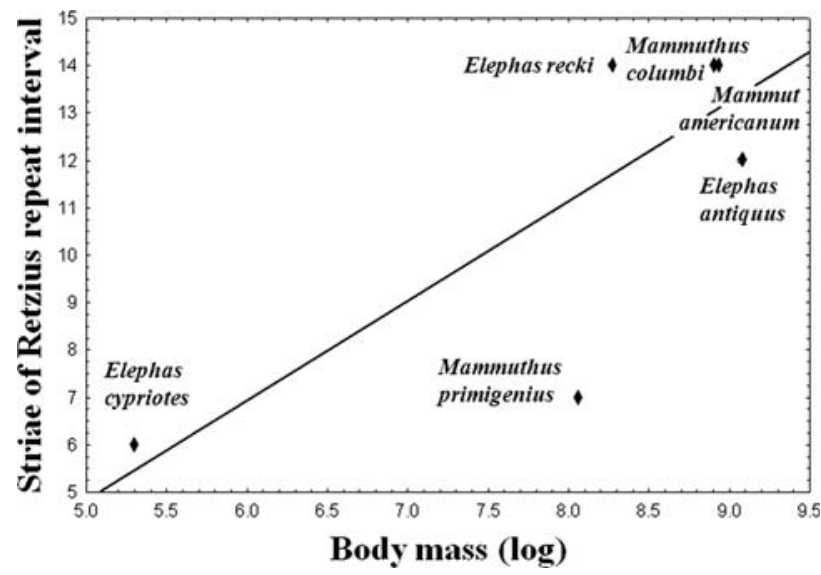

Fig. 3 Striae of Retzius repeat interval (RI) linearly regressed against log body mass for proboscideans (least squares model). The number of daily cross striations between striae of Retzius is referred to as the RI. Raw data provided in Table 3. Summary statistics are as follows: $r=0.79, \quad p=0.03, r^{2}=0.62$, $y=5.649+2.098 * x$. The $X$-axis represents the $\log$ of body mass measured in kilograms

osteocyte densities from the midshaft femur of eight primate and three nonprimate taxa (Table 4). Primary lamellar or parallel-fibered bone sites could be measured for most taxa. However, only secondary osteonal lamellae were available for measurement on the modern human lateral periosteal cortex selected and on the modern and fossil hippo material. Results indicate that osteocyte density is inversely proportional to body mass for mammals, the relationship being described by $r=-0.85, p<0.01$,

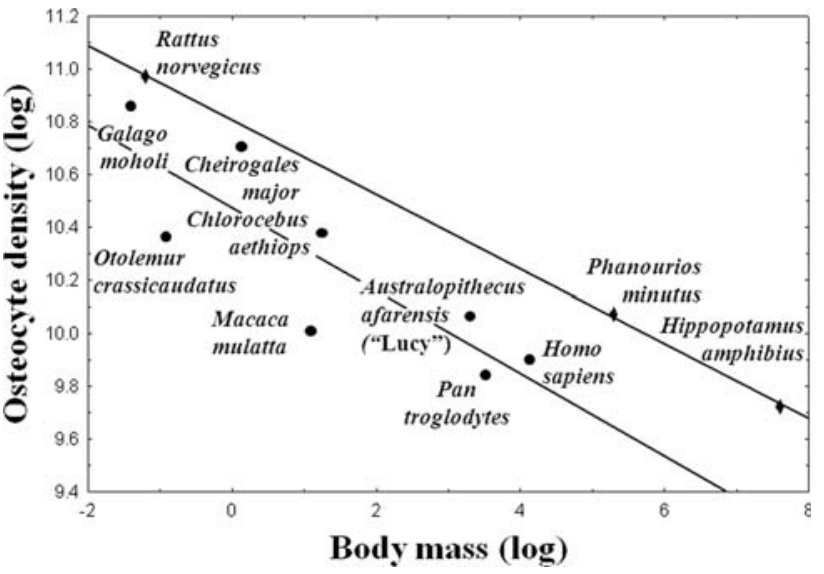

Fig. 4 Log osteocyte density linearly regressed against log body mass for primates and selected nonprimate mammals $(\bullet)$ (least squares model). Raw data are provided in Table 4 . When all primates and mammals examined here are treated together, the relationship is described by $r=-0.85, p<0.01, r^{2}=0.72, y=10.500-0.122 *$ $x$. Summary statistics for primates are $r=-0.84, p=0.01$, $r^{2}=0.71, y=10.500-0.149 * x$; for selected mammals, $r=$ $-0.99, p=0.01, r^{2}=0.99, y=10.804-0.144 * x$; and for the sample of five humans, $r=-0.97, p<0.01, r^{2}=0.99, y=8.040+$ $0.458 * x$. The $X$-axis represents the $\log$ of body mass measured in kilograms

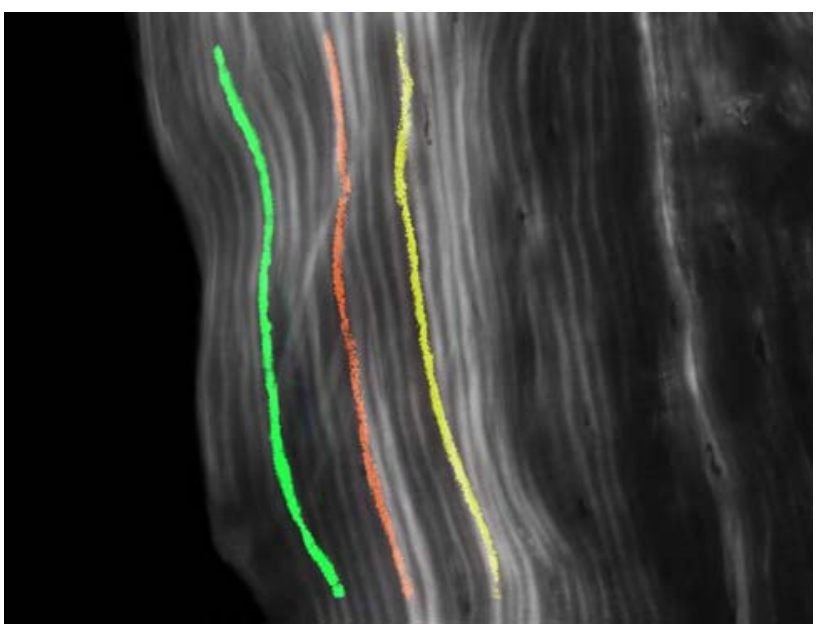

Fig. 5 Circularly polarized light image of primary lamellar bone from the midshaft femur of a growing macaque, Macaca nemestrina $(\mathrm{FW}=237 \mu \mathrm{m}$; Table 5), with growth direction from right to left. Vital labels were administered at 2-week intervals, labeling the forming front with minocycline (yellow), xylenol orange, and, finally, DCAF (green). The animal was killed 18 days following the last label. The image of vital labels is truncated at the top and bottom to permit visualization of the association between label and lamellae

$r^{2}=0.72, y=10.500-0.122 * x$ (Fig. 4). In contrast, the relationship between osteocyte lacuna density and body mass within the modern human sample is positive and described by $r=0.97, p<0.01, r^{2}=0.99, y=8.040+0.458 * x$ (regression not shown; see Table 4 for raw data). 
Striae of Retzius Repeat Interval Compares to the Lamellar Formation Rate

\section{Primary Lamellar Bone}

We imaged primary lamellar bone separately from secondarily remodeled lamellar bone tissue, recording the number of lamellae formed between vital labels when the number of days between the administration of vital labels was known or could be inferred (Table 5). In each case we find that one lamella is formed in the period matching the species-specific striae of Retzius repeat interval (e.g., Fig. 5, Table 5). Of note, patas monkey label fluorescence is saturated over three lamellae, with only a partial lamella following the last label, which is consistent with its repeat interval. Also, vital labels in the human (Fig. 5) are presumed to be 7- to 10-day treatment courses of tetracycline antibiotic; this duration would label only one lamella, which is consistent with the range of human repeat intervals.

\section{Secondarily Remodeled Lamellar Bone}

Having confirmed that the lamellar formation rate in primary lamellar bone corresponds with the striae of Retzius repeat interval, we were also concerned to know if lamellae formed during a secondary remodeling event and contained within an osteon would provide the same result. Fluorescence microscopy of our prepared 'ground' thin sections of the midshaft femur of postadolescent humans revealed vital labels inferred to be therapeutic courses of tetracycline antibiotic. In these individuals, multiple labels could be identified both in primary lamellar bone laid down during growth and in secondary remodeled osteonal bone laid down during bone maintenance (e.g., Fig. 6). There are two important observations to make about the images of human lamellae presented in Fig. 6. First, there exists a mix of reasonably clear primary and secondary osteonal lamellae, which, in both tissue types around the 10th or 11th lamella, becomes more difficult to discern. This suggests that the physiological milieu responsible for lamella formation is similar between the two circumstances. Second is a caveat described under Materials and Methods, which is because of drift in the course of the forming secondary osteon, the cross section does not represent lamellae equally when counted on one side and then the other; this must be taken into account when enumerating lamellae.

We also observed primary lamellar and secondary osteonal lamellae in sheep labeled at known intervals (Fig. 7, Table 5), and as observed for human, the number of lamellae between labels is identical between the two lamellar tissue types.

\section{Discussion}

Our aim has been to conduct a series of tests to determine if lamellar bone is an incremental tissue having relevance to interpretations of organismal life history, as has been widely recognized for enamel. The first test, using modern and fossil primates and proboscideans, was designed to test the relationship between enamel striae of Retzius repeat intervals and body mass. The second test, employing primates and a few nonprimate mammals, examined the relationship between rates of lamellar bone growth and body mass, where osteocyte density was used as a surrogate for rates of bone cell proliferation in lamellar bone. Having established these relationships with body mass, the conditions were set for testing the correspondence between enamel striae of Retzius and lamellar bone development.

\section{Striae of Retzius Repeat Interval Correlates with Body} Mass

Our analysis of the relationship between striae of Retzius repeat interval and body mass was performed on the largest
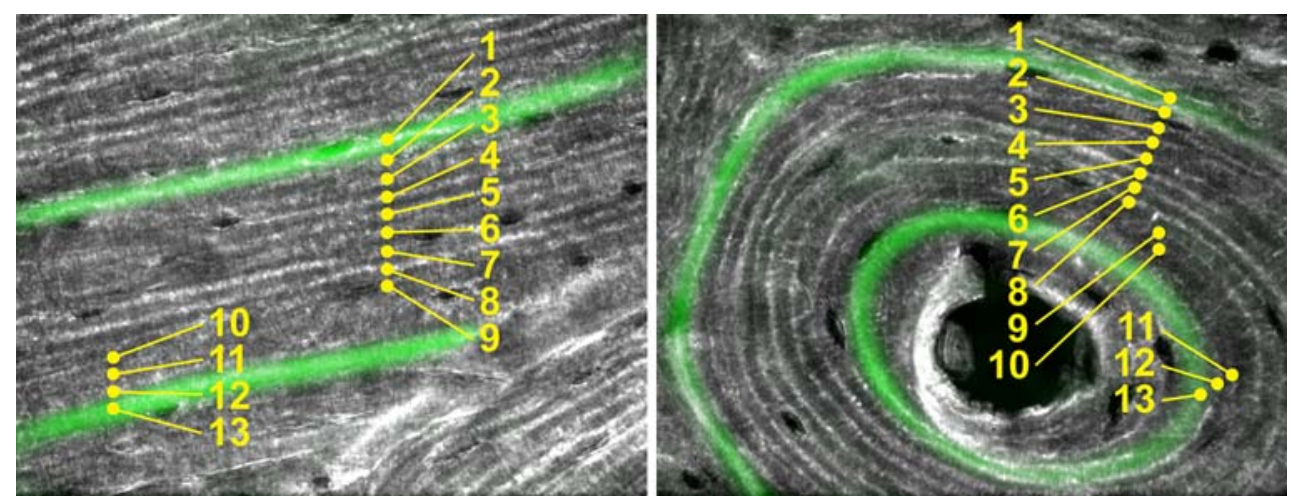

Fig. 6 Primary and secondary osteonal lamellae from the midshaft femur of a 38-year-old human female (FW = $237 \mu \mathrm{m}$ for each image). The same numbers of lamellae are formed during bone growth and maintenance 


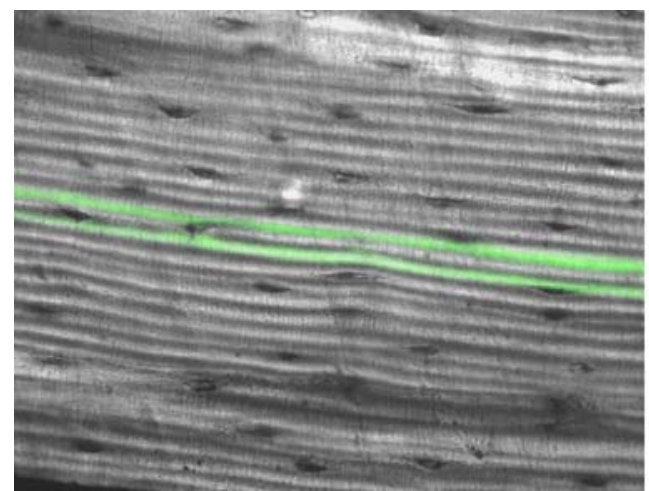

Fig. 7 Primary and secondary osteonal lamellae from the midshaft femur of a female sheep ( $F W=237 \mu \mathrm{m}$ for each image; Table 5). Two lamellae are contained within the 11-day labeling protocol,

and most taxonomically diverse sample of mammalian species to date. Significant correlations were found between these two variables, which hold true not only for the order Primates generally, including fossil hominins, but also for members of the Proboscidea, which include insular-dwarf forms. There is thus a clear association between mammalian long-period tooth growth rhythms and body mass, with a noted exception in one group of primates, the strepsirrhines (subfossil giant lemurs) having very low repeat intervals for their body mass [27]. When this is considered in light of our results on the relationship between bone and tooth development, this interesting exception may be explained (see below).

In addition to the interspecific comparisons examined here, the relationships between striae of Retzius repeat interval and body mass may also help to explain longperiod variability within a species. Repeat intervals in Homo sapiens are highly variable, but modern humans also have an unusually high body mass variability for a primate. Preliminary research by us on six humans of known life history provides a statistically significant negative relationship between striae of Retzius repeat interval and body height (weight was extremely variable in the sample), suggesting that long period rhythms influence body size in humans (data not shown). Interspecifically, the relationship between repeat interval and body mass is positive, indicating that body mass increases are accomplished by slowing developmental rates over longer growth periods; i.e., larger-bodied species are characterized by relatively protracted life histories. Within a species and life history gamut, such as suggested by our preliminary research on humans, increases in body mass are at least partly accomplished by increasing the developmental rate within the same growth period and life history; i.e., the longperiod rhythm is shortened. Long-period rhythm variation relative to body mass thus offers a potential, if not partial, solution to questions of life history variation, while

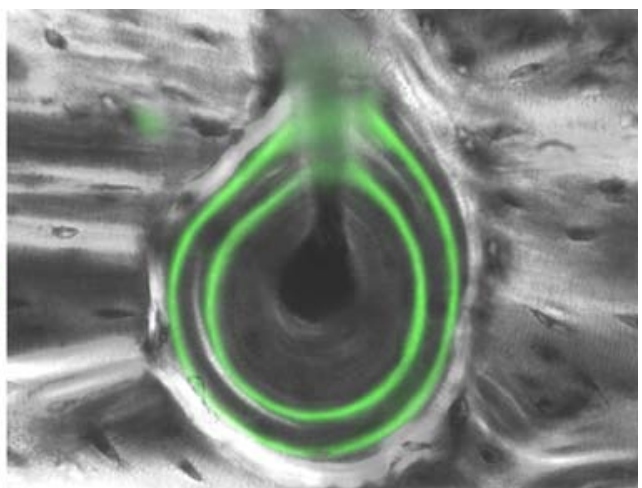

consistent with a 5-day striae of Retzius repeat interval. The same numbers of lamellae are formed during bone growth and maintenance

remaining cognizant of other genetic factors responsible for growth factors operating within what are otherwise restricted genetic/historical programs [28, 29].

\section{Osteocyte Lacuna Density Correlates with Body Mass}

Based on the observed relationship between striae of Retzius repeat interval and body mass, and our appreciation for the scaling of bone mass to body mass, we advanced the working hypothesis that proliferation rates of osteoblasts, which become embedded in bone as osteocytes, vary with body mass. Osteocyte density is of special significance in this connection because, while osteoblast fates and functions are complex [30] (e.g., only a subpopulation are destined to become osteocytes), the positive relationship between osteoblast density and the proportion of osteoid surface covered by osteoblasts [31] permits specific predictions to be made concerning osteocyte density and life history. Osteocyte lacuna densities, as they reflect the rate of osteoblast proliferation, transformation, and incorporation into bone as osteocytes during growth, should be higher in organisms with rapid growth, with a small body mass, and whose osteoblast proliferation rates would lead to higher osteocyte lacuna densities; i.e., an inverse relationship between osteocyte density and body mass. No analysis has been performed to examine such a relationship within a mammalian order. We thus opted to test this hypothesis with a selection of very small to large primate and nonprimate mammal midshaft femurs (Table 4) and found that, indeed, osteocyte density is inversely proportional to body mass (Fig. 4). We ignored osteocyte apoptosis for the main reason that our interest in the development of bone mass as it relates to body mass concerns only the rate of osteoblast proliferation and the production of bone matrix by actively secreting cells. While osteocyte apoptosis most certainly occurs in some small percentage of cells, this is not a principal concern for 
analyses of the rate at which osteoblasts becomes embedded in the bone matrix; our interest here is independent, at least relatively so as far as we know presently, of the living bone cell population.

Mullender and colleagues [32] found a similar relationship for osteocyte lacuna densities within the cancellous bone tissues of the proximal femur in five mammals, speculating that osteocyte density is related to rates of osteoblast proliferation and obeys scaling laws relating to body mass, metabolic rate, life span, and growth rate. The well-recognized reduction in the capacity for cell proliferation during postreproductive aging and disease notwithstanding [33], the inverse relationship of osteocyte number per unit lamellar bone volume with body size thus appears to be an indicator of organismal life history; the faster the life history and skeletal development, the faster are osteoblast mitotic rates (the extent to which osteocyte density in woven bone tissue may be similarly interpreted is an area worth further investigation [34]).

Though the sample is small and the analysis preliminary, it is interesting that the relationship between osteocyte lacuna density and body mass in the modern human sample is positive. Interspecifically, the relationship is negative, indicating that body mass increases are accomplished by slowing developmental rates over longer growth periods; i.e., larger-bodied species are characterized by relatively protracted life histories. However, within the human species, body mass increases are accomplished by increasing the developmental rate. These inter- and intraspecific interpretations match those described for the relationship between repeat interval and body mass above.

\section{Striae of Retzius Repeat Interval Correlates}

with Lamellar Bone Formation Rate

The bone lamellae of all mammals are strikingly similar in character, typical widths falling in the range of 3-6 $\mu \mathrm{m}$, though thinner and much wider widths have been reported (to date there is no formal comparative mammalian study of lamellar widths). The lamellar design is one commonly associated with incremental patterns comprised of a layered structure, such as that represented by enamel cross striations, each layer being developed during one cycle of growth [25]. The temporal association of enamel formation being known, it was our aim to examine lamellar formation rates in mammals for which the times of administration of the labels were known or could be inferred (see Materials and Methods and Table 5).

In each case we found that one lamella is formed in the period matching the species-specific striae of Retzius repeat interval (e.g., Fig. 5, Table 5). For example, in the pigtailed macaque (Fig. 5), one vital label to the next was observed to contain between three and four lamellae, followed by four or five lamellae from the last label to the end of growth, which is consistent with a lamellar formation rate of 4 days/lamella and the striae of Retzius repeat interval for this taxon [8]. The lamellar structure in Fig. 5 contains some anisotropy, however, which is increased in the lower portion of the image. Concerning this anisotropy, there are two points to note. First, where one lamella is observed in the upper portion of this image, two may arise below. Second, the fluorescence image derives from a single confocal plane overlain onto a circularly polarized light image of the full section thickness, thus vital labels are observed to waver slightly around lamellae; i.e., this is a result arising because of our optical methods. Both of these phenomena are explained by the anisotropy discussed under Materials and Methods, which is informative and helps us to appreciate the three-dimensional complexity of forming bone surfaces.

In both humans and sheep it was also found that the lamellar formation rate was identical in both primary lamellar bone laid down during growth and secondary remodeled osteonal bone laid down during bone maintenance. Evidence for primary and secondary lamellar bone formation combined demonstrates that lamellar bone is an incremental tissue with a consistent time-dependent developmental morphology, similar to that described for enamel.

\section{Long-Period Rhythms and Organismal Life History}

Because the bone organ provides mechanical support for body mass, developmental rates for body mass should reflect developmental rates for bone mass. We thus hypothesize that the metabolic rhythm affecting osteoblast behavior and lamellar bone formation sets the pace of skeletal development; the effect this rhythm has on ameloblast function and enamel formation is secondary. Specifically, our morphological research supports the hypothesis that lamellar bone is an incremental tissue and that one lamella, mirrored by the stria of Retzius repeat interval in enamel, represents a centrally regulated longperiod rhythm controlling bone and body mass. The functional significance of this is central to the evolution of vertebrate life histories. This hypothesized period, we suggest, is deeply integrated with the neuroendocrine functions of leptin in its control of bone and body mass, and most probably the role of osteocalcin in metabolism [35-38] (see theoretical remarks below). The posited function of this long period clock is to regulate osteoblast proliferation and matrix secretion and whole-body metabolism [35, 36]. Provided that taxon-specific striae of Retzius repeat intervals are available or that long-period metabolic signatures will be identified in future research, bone lamellae may be calibrated in time. This will permit 
analyses of growth rate variability as a primary source of information about the duration and amplitude of growth, periodic phenomena, and other natural history events occurring during hard tissue formation. Lamellar bone can be evaluated over known time intervals for the durations of experimental protocols or in studies of metabolic dysfunction or disease affecting hard tissue formation.

Information about biological periodicities, environmental and/or physiological cycles, and perturbations to the developing organism are all potentially contained in growth rate variability studies of lamellar incremental patterns. For instance, given that lamellae are formed within defined periods of time, quantitative measures of widths of individual lamellae may provide time-resolved growth rate variability and reveal rhythms heretofore unknown. An image of fossil hominin (Paranthropus robustus) lamellar bone, calibrated at 7 days/lamella, which is the striae of Retzius repeat interval for this taxon (Table 2), reveals a long-period rhythm resembling the lunar cycle, not previously observed in bone (Fig. 8).

As noted above, the subfossil lemur, Palaeopropithecus ingens, is an exception, having a lower repeat interval for its body size than observed for primates generally. Exceptions of this nature have the potential of offering wonderful insight into life history processes, and in this case, the correspondence between repeat intervals and lamellar formation enables us to reconcile the enigmatic relationship between their rapid dental development and their estimated large body size of $45 \mathrm{~kg}$. In the absence of any knowledge of the incremental nature of their skeletal development, one plausible interpretation would be that the pace of dental and somatic growth was decoupled, allowing the dentition to form quickly in relation to a slowergrowing body. However, we hypothesize that dental and skeletal development are in a manner coupled, and that the very short, 2-day, striae of Retzius repeat interval in these primates relates specifically to their large size, achieved by retaining a historically constrained rapid lamellar formation rate over a somewhat prolonged period of somatic development.

The hypothesized long-period rhythm is thus worthy of future study both as a potential analytical tool and as a paradigm for analyses of organismal life history variation and evolution. Quite apart from its effects on hard tissues, the hypothesized rhythm is also related to the overall pace of development and life at high taxonomic levels. We suggest that this long period likely regulates size and rate variation, which coordinate the organismal life history gamut [39]. The lower height of the primate osteocyte production function (Fig. 4), for instance, agrees with growth law predictions indicating that primate production energy is significantly less compared with other mammals of the same body size [40]. These predictions are part of a larger model, which explains that growth energy determines also how much energy is available for reproduction later. This suggests that production rate, bone and body size, and reproduction are centrally linked to this longperiod rhythm, which is a mediating mechanism in the regulation of organismal life history according to metabolic constraints [41]. These mechanisms may also regulate the cell proliferation rates of some soft tissues and thus of increases in body organ masses during postnatal

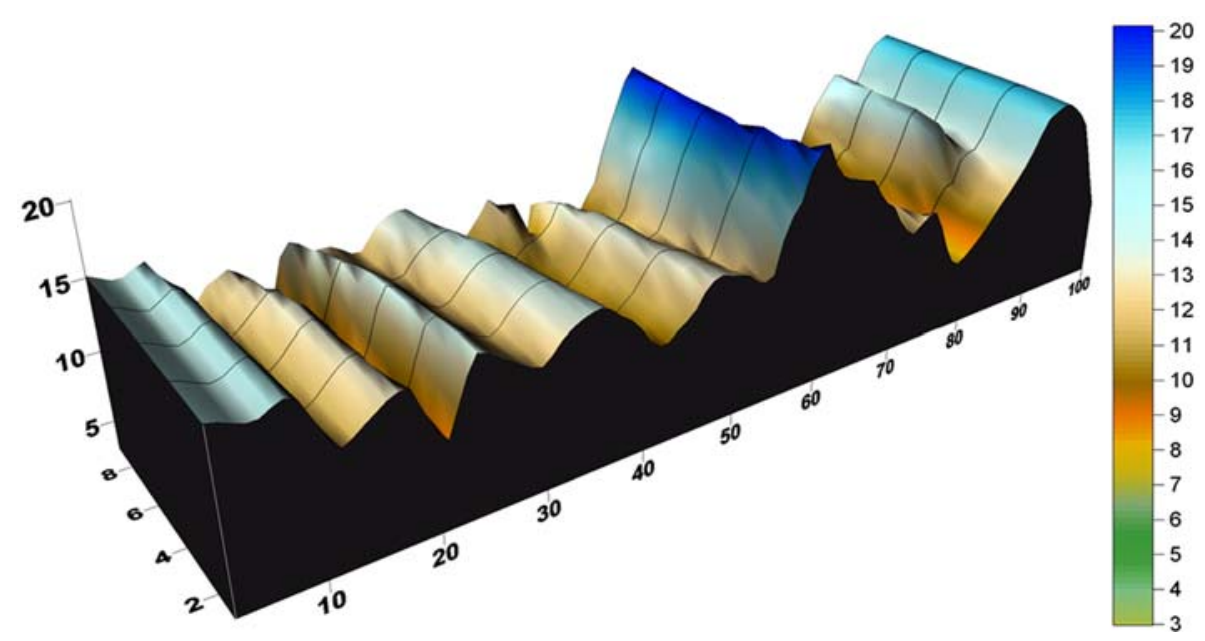

Fig. 8 Lamellar growth rate variability of Paranthropus robustus metacarpal (SK 3646) lamellae is based on a method developed for assessment of growth rate of anisotropic incremental structures [25]. The $Z$-axis represents lamellar width, or growth rate in micrometers, according to the color-coded scale; the $X$-axis is a relative time scale of the growth rate in two dimensions, where $X=0$ is at the beginning and $X=100$ is at the end of the lamellar growth sequence; the $Y$-axis denotes different levels of structural lamellar detail, where $Y=0$ refers to the most basic elements of the lamellar structure and $Y=9$ means that all structural elements associated with nine measurement transects were taken into account. Based on a 7- day period for Paranthropus robustus (Table 2) and a number of lamellae near to 35 in the original image, lamellar growth rate illustrates a periodicity of roughly 4 weeks 
development. Cell division rates in vivo appear to regulate longevity [42] and thus the integrative study of long period rhythms and local aging mechanisms (e.g., neuroendocrine imbalance, DNA repair and metabolism, and related genetic disorders) is expected to provide insight on their combined influence on longevity and the aging process. We expect future neuroendocrine and physiological research to identify the role of long-period developmental rhythms and address such suggestions.

\section{A Hypothesis for Central Control of Long-Period Rhythms and Bone/Body Mass in Mammals}

Research on biological rhythms in mammals has revealed a suite of well-known circadian oscillations that regulate fundamental day-to-day metabolic requirements, growth, and maintenance of the organism [1]. However, concentrations on circadian biological rhythms, particularly those established using "gold standards" based on small-bodied mice, rats, or hamsters, whose rhythmic growth is fast, would miss fundamental long-period physiological rhythms regulating developmental rates in organisms having slower and longer life histories. Slow-growing and large-bodied organisms have protracted life histories that suggest the possibility of long-period physiological and developmental regulation. A long-period rhythm might explain how the slow growth rate and protracted life history of a large-bodied organism can be achieved by its cells proliferating over a longer period than that of a circadian rhythm.

One long-period rhythm has been noticed; a circaseptan (near-7-day) periodicity in heart rate and pressure has been demonstrated in humans [43-45]. Furthermore, it has been specifically suggested that this centrally regulated autonomic, sympathetic-mediated heart rate and pressure oscillation in humans relates to striae of Retzius repeat intervals [43], which have a modal frequency of 8 days [13]. We conjecture that the resemblance between circaseptan variability in sympathetic drive (tone) and striae of Retzius formation in humans is no coincidence, and that they are physiological manifestations of a centrally regulated biological rhythm. Such periodic rhythms, we believe, are likely to be driven by an oscillator rather than an hourglass mechanism, the latter of which, for instance, explain single life events in an organism (e.g., menopause) [46].

As described above, the relationship between osteocyte lacuna density and body mass suggests that many cells, a proportion of which are subsequently incorporated as osteocytes, are required to form a single lamella during a relatively brief period in a small mammal, but that fewer mitoses would be required in the development of a largebodied organism, their osteoblasts forming one lamella over a longer period of time. An important body of work has recently demonstrated that leptin-bound receptors in the hypothalamus mediate sympathetic inhibition of osteoblast proliferation through the $\beta 2$-adrenergic receptor, thus exerting control of bone mass [36-38, 47]. This research has shown that leptin-mediated control of bone mass is complementary to leptin's other hypothalamic actions relating to appetite, satiety, and regulation of body mass. It has also been shown that integrity of the peripheral (i.e., osteoblast population) molecular clock is necessary for this regulatory system to operate. A necessary coadaptive feature of body mass variation is its relationship with bone mass: i.e., a bone mass consistent with the support of body mass. Takeda and colleagues [48] have highlighted the importance of several discrete hypothalamic nuclei for integrated leptin-mediated autonomic control of bone and body mass and reproduction.

Recently the endoluminal release of serotonin by enterochromaffin cells of the duodenum has also been demonstrated to regulate (inhibit) osteoblast proliferation and bone formation through the cAMP response element binding (CREB) transcription mediator [49]. CREB is as well implicated in sympathetic inhibition of osteoblast proliferation through the $\beta 2$-adrenergic receptor, as mentioned above. While the parasympathetic nervous system may be one link in the autonomic regulation of bone mass via vagal pathways, efferent stimulation of splanchnic nerves of the sympathetic nervous system also cause release of duodenal serotonin through a $\beta 2$-adrenergic mechanism [50], raising the possibility of a two-pronged central sympathetic regulatory system for controlling bone mass.

A hypothesized autonomic long-period rhythm controlling osteoblast proliferation and striae of Retzius repeat intervals agrees with data presented on mammalian osteocyte density. Thus we believe that a strong circumstantial case exists for central autonomic control of long-period rhythms over aspects of life history such as body mass. We term this hypothesized period the Havers-Halberg Oscillation, with reference to Clopton Havers [51], the first to observe and describe both the lamellae in bone and the striae of Retzius in enamel, and Franz Halberg, a long-time explorer of long-period rhythms [52, 53].

We wish to add, however, that it remains to be determined whether there are circumstances concerning continuously forming bone surfaces in which the correspondence between striae of Retzius repeat intervals and the formation of lamellae falters. In a 38-year-old (Fig. 6) and a 41-year-old human female (data not shown), both primary and secondary osteonal lamellar tissues were simultaneously labeled during a time in these women's lives when they were still growing, the two bone tissue types in each individual exhibiting an identical number of 
lamellae between labels. However, while we believe it to be unlikely that a centrally regulated long-period rhythm would change with age, we have not tested for its maintenance in the aged. Further, it must be determined whether there are any pathological conditions that might alter longperiod and lamellar formation rhythms, operable through the SCN and/or in combination with other hypothalamic nuclei and peripheral clocks.

In sum, and in wait for further experimental testing, we propose that vertebrate long-period rhythms are a function of natural selection operating on a hypothalamic autonomic clock responsible for the pace of development and bone/ body mass, the study of which we believe holds much promise for the integrative science of organismal life history.

Acknowledgments This research was funded by the L. S. B. Leakey Foundation, the Blanquer and March Foundations, the PalaeoAnthropological Scientific Trust, and D. McSherry to T.G.B., R.L., and A.P.-O. and by the L. S. B. Leakey Foundation and NSF Doctoral Dissertation Improvement Grants to R.H., H.M.G., S.C.M., and J.W. Additional support to T.G.B. was provided by the New York University College of Dentistry and the Waldmann Dental Library. Discussions with Otto Appenzeller, Franz Halberg, Hisashi Shinoda, and Shu Takeda enlightened our research focus. To each of the numerous individuals and institutions that provided specimens listed in Tables 1-5 we are grateful, particularly John Clement, Joseph Erwin, Patrick Hof, Bruce Martin, Emma Mbua, Rasime Öner, Francis Thackeray, Phillip Tobias, Simon Turner, and Mamitu Yilma; we are also thankful to Christina Hintze for the translation of Okada and Mimura (1940).

Open Access This article is distributed under the terms of the Creative Commons Attribution Noncommercial License which permits any noncommercial use, distribution, and reproduction in any medium, provided the original author(s) and source are credited.

\section{References}

1. Nagai K, Nakagawa H (1992) Central regulation of energy metabolism with special reference to circadian rhythm. CRC Press, Boca Raton, FL

2. Klevezal GA (1996) Recording structures of mammals: determination of age and reconstruction of life history. A. A. Balkema, Rotterdam

3. Ricqles AD, Meunier F, Castanet J, Francillon-Vieillot H (1991) Comparative microstructure of bone. In: Hall B (ed) BoneVolume 3: bone matrix and bone specific products. CRC Press, Boca Raton, FL, pp 1-78

4. Enlow DH, Brown SO (1956-1958) A comparative histological study of fossil and recent bone tissues. Parts I and II. Tex J Sci 8:405-443, 9:186-214, 10:187-230

5. Ascenzi A, Bonucci E, Bocciarelli DS (1967) An electron microscope study on primary periosteal bone. J Ultr Res 18:605618

6. Shinoda H, Okada M (1988) Diurnal rhythms in the formation of lamellar bone in young growing animals. Proc Jpn Acad Ser B 64:307-310

7. Okada M, Mimura T (1940) Zur Physiologie und Pharmakologie der Hartgewebe. IV. Mitteilung: Tagesrhythmus in der Knochenlamellenbildung. Proc Jpn Pharm Soc 95-97
8. Smith TM (2006) Experimental determination of the periodicity of incremental features in enamel. J Anat 208:99-113

9. Dean MC (1987) Growth layers and incremental markings in hard tissues, a review of the literature and some preliminary observations about enamel structure of Paranthropus boisei. J Hum Evol 16:157-172

10. Boyde A (1989) Enamel. In: Berkovizt BKB, Boyde A, Frank RM, Hohling HJ, Moxham BJ, Nalbandian J, Tonge CH (eds) Teeth. Handbook of microscopic anatomy. Springer-Verlag, Berlin, pp 309-473

11. Retzius A (1837) Bemerkungen qber den inneren Bau der Zähne, mit besonderer Rücksicht auf dem in Zahnknochen vorkommenden Röhrenbau. Arch Anat Physiol 486-566

12. Fitzgerald CM (1998) Do enamel microstructures have regular time dependency? Conclusions from the literature and a largescale study. J Hum Evol 35:371-386

13. Smith TM (2008) Incremental dental development: methods and applications in hominoid evolutionary studies. J Hum Evol $54: 205-224$

14. Dean MC, Scandrett AE (1995) The relationship between longperiod incremental markings in dentine and daily cross-striations in enamel in human teeth. Arch Oral Biol 41:233-241

15. Schmidt-Nielsen K (1984) Scaling: why is animal size so important?. Cambridge University Press, Cambridge

16. Bromage TG, Smolyar I, Doty SB, Holton E, Zuyev AN (1998) Bone growth rate and relative mineralization density during space flight. Scanning 20:238-239

17. Newell-Morris L, Sirianni JE (1982) Parameters of bone growth in the fetal and infant macaque (Macaca nemestrina) humerus as documented by trichromatic bone labels. In: Dixon AD, Sarnat BG (eds) Factors and mechanisms influencing bone growth. Alan R. Liss, New York, pp 243-258

18. Metz LN, Martin RB, Turner AS (2003) Histomorphometric analysis of the effects of osteocyte density on osteonal morphology and remodeling. Bone 33:753-759

19. Boyde A (1984) Methodology of calcified tissue specimen preparation for SEM. In: Dickson GR (ed) Methods of calcified tissue preparation. Elsevier, Amsterdam, pp 251-307

20. Goldman HM, Kindsvater J, Bromage TG (1999) Correlative light and backscattered electron microscopy of bone. Part I: specimen preparation methods. Scanning 21:40-43

21. Greenberg GL, Boyde A (1997) Convenient and controllable direct-view 3D imaging in conventional optical microscopes: approaches via illumination and inspection. Proc Roy Microsc Soc 32:87-100

22. Bromage TG, Goldman HM, McFarlin S, Warshaw J, Boyde A, Riggs C (2003) Circularly polarized light standards for investigations of collagen fiber orientation in bone. Anat Rec New Anat 274B:157-168

23. Bromage TG, Lacruz RS, Perez-Ochoa A, Boyde A (2007) Portable confocal scanning optical microscopy of Australopithecus africanus enamel microstructure. In: Bailey S, Hublin JJ (eds) Dental palaeoanthropology. Springer, Berlin, pp 191-207

24. Boyde A, Hobdell MH (1969) Scanning electron microscopy of lamellar bone. Z Zellforsch 93:213-231

25. Smolyar I, Bromage TG (2004) Discrete model of fish scale incremental pattern A formalization of the $2 \mathrm{~d}$ anisotropic structure. ICES J Mar Sci 61:992-1003

26. Lacruz RS, Dean MC, Ramirez-Rozzi F, Bromage TG (2008) Megadontia, striae periodicity, and patterns of enamel secretion in Plio-Pleistocene fossil hominins. J Anat 213:148-158

27. Schwartz GT, Samonds KE, Godfrey LR, Jungers WL, Simons EL (2002) Dental microstructure and life history in subfossil Malagasy lemurs. Proc Natl Acad Sci USA 99:6124-6129

28. Zhu L, Padhukasahasram B, Karlins E, Davis S, Jones PG, Quignon P, Johnson GS, Parker HG, Fretwell N, Mosher DS, 
Lawler DF, Satyaraj E, Nordborg M, KGo Lark, Wayne RK, Ostrander EA (2007) A single IGF1 allele is a major determinant of small size in dogs. Science 316:112-115

29. Davila N, Shea BT, Omoto K, Mercado M, Misawa S, Baumann G (2002) Growth hormone binding protein, insulin-like growth factor-I and short stature in two pygmy populations from the Philippines. J Pediatr Endocrinol 15:269-276

30. Franz-Odendaal TA, Hall BK, Witten PE (2006) Buried alive: how osteoblasts become osteocytes. Dev Dynam 235:176-190

31. Qui S, Palnitkar S, Rao D, Parfitt AM (2000) Is osteocyte density affected by osteoblastic changes in bone remodeling? J Bone Min Res 15:S236

32. Mullender MG, Huiskes R, Versleyen H, Buma P (1996) Osteocyte density and histomorphometric parameters in cancellous bone of the proximal femur in five mammalian species. J Orthop Res 14:972-979

33. Mullender MG (1996) Osteocyte density changes in aging and osteoporosis. Bone 18:109-113

34. Hernandez CJ, Majeska RJ, Schaffler MB (2004) Osteocyte density in woven bone. Bone 35:1095-1099

35. Lee NK, Sowa H, Hinoi E, Ferron M, Ahn JD, Confavreux C, Dacquin R, Mee PJ, McKee MD, Yung JD, Zhang Z, Kim JK, Mauvais-Jarvis F, Pucy D, Karsenty G (2007) Endocrine regulation of energy metabolism by the skeleton. Cell 130:456469

36. Karsenty G (2006) Convergence between bone and energy homeostases: leptin regulation of bone mass. Cell Metab 4:341-348

37. Elefteriou F, Takeda S, Ebihara K, Magre J, Patano N, Kim CA, Ogawa Y, Liu X, Ware SM, Craigen WJ, Robert J, Vinson C, Nakao K, Capeau J, Karsenty G (2004) Serum leptin level is a regulator of bone mass. Proc Natl Acad Sci USA 101:3258-3263

38. Ducy P, Amling KM, Takeda KS, Priemel M, Schilling AF, Beil FT, Shen J, Vinson C, Rueger JM, Karsenty G (2000) Leptin inhibits bone formation through a hypothalamic relay: a central control of bone mass. Cell 100:197-207

39. Harvey PH, Clutton-Brock TH (1985) Life history variation in primates. Evolution 39:559-581

40. Charnov EL, Berrigan D (1991) Why do female primates have such long lifespans and so few babies? or life in the slow lane. Evol Anthropol 1:191-194

41. Brown JH, Sibly RM (2006) Life-history evolution under a production constraint. Proc Natl Acad Sci USA 103:17595-17599

42. Magalhães JPd, Faragher RGA (2009) Cell divisions and mammalian aging: integrative biology insights from genes that regulate longevity. BioEssays (in press)

43. Appenzeller O, Gunga H-C, Qualls C, Furlan R, Porta A, Lucas SG, Heckert AB, Kirsch K, Costa-Junqueira MA, Guillén SE, Sander M, Schneider T, Blottner B (2005) A hypothesis: autonomic rhythms are reflected in growth lines of teeth in humans and extinct archosaurs. Auto Neuro Basic Clin 117:115-119

44. Rawson MJ, Cornélissen G, Holte J, Katinas G, Eckert E, Siegelová J, Halberg F (2000) Circadian and circaseptan components of blood pressure and heart rate during depression. Scr Med (Brno) 73:117-124

45. Wu JY, Cornélissen G, Tarquini B, Mainardi G, Cagnoni M, Fernández JR, Hermida RC, Tamura K, Kato J, Kato K (1990) Circaseptan and circannual modulation of circadian rhythms in neonatal blood pressure and heart rate. Prog Clin Biol Res 341A:643-652

46. Schibler U (2005) The daily rhythms of genes, cells and organs. EMBO Rep 6:S9-S13

47. Rosen CJ (2008) Bone remodeling, energy metabolism, and the molecular clock. Cell Metab 7:7-10

48. Takeda S, Elefteriou F, Karsenty G (2003) Common endocrine control of body weight, reproduction, and bone mass. Annu Rev Nutr 23:403-411
49. Yadav VK, Ryu J-H, Suda N, Tanaka KF, Gingrich JA, Schütz G, Glorieux FH, Chiang CY, Zajac JD, Insogna KL, Mann JJ, Hen R, Ducy P, Karsenty G (2008) Lrp5 controls bone formation by Inhibiting serotonin synthesis in the duodenum. Cell 135:825837

50. Larson I, Dahlström A, Pettersson G, Larsson P-A, Kewenter J, Ahlman H (1980) The effects of adrenergic antagonists on the serotonin levels of feline enterochromaffin cells after splanchnic nerve stimulation. J Neural Transm 47:89-98

51. Havers C (1691) Osteologia nova, or some new observations of the bones, and the parts belonging to them with the manner of their accretion and nutrition. Samuel Smith, London

52. Halberg F, Otsuka K, Katinas G, Sonkowsky R, Regal P, Schwartzkopff O, Jozsa R, Olah A, Zeman M, Bakken EE, Cornélissen G (2004) A chronomic tree of life: ontogenetic and phylogenetic 'memories' of primordial cycles-keys to ethics. Biomed Pharmacol 58:S1-S11

53. Halberg F, Engell M, Hamburger C, Hillman D (1965) Spectral resolution of low-frequency, small-amplitude rhythms in excreted ketosterold; probable androgen-induced circaseptan desynchronization. Acta Endocrinol Suppl 103:1-54

54. Leakey MG, Walker A (1997) Afropithecus function and phylogeny. In: Begun DR, Ward CV, Rose MD (eds) Function, phylogeny, and fossils: Miocene hominoid evolution and adaptations. Plenum Press, New York, pp 225-239

55. Smith TM, Martin LB, Reid DJ, Bonis LD, Koufos GD (2004) An examination of dental development in Graecopithecus freybergi (=Ouranopithecus macedoniensis). J Hum Evol 46:551577

56. Andrews P, Martin LB (1991) Hominoid dietary evolution. Philos Trans Biol Sci 334:199-209

57. Kelley J, Dean MC, Reid DJ (2001) Molar growth in the late Miocene hominoid, Dryopithecus laietanus. In: Brook A (ed) Dental morphology. Sheffield Academic Press, Sheffield, pp 123134

58. Dean MC, Schrenk F (2003) Enamel thickness and development in a third permanent molar of Gigantopithecus blacki. J Hum Evol 45:381-387

59. Schwartz GT, Reid DJ, Dean MC (2001) Developmental aspects of sexual dimorphism in hominoid canines. Int $\mathrm{J}$ Primatol 22:837-860

60. Smith TM, Martin LB, Leakey MG (2003) Enamel thickenss, microstructure and development in Afropithecus turkanensis. J Hum Evol 44:283-306

61. Dirks W, Bowman JE (2007) Life history theory and dental development in four species of catarrhine primates. J Hum Evol 53:309-320

62. Dirks W (1998) Histological reconstruction of dental development and age at death in a juvenile gibbon (Hylobates lar). J Hum Evol 35:411-426

63. Smith TM, Reid DJ, Dean MC, Olejniczak AJ, Martin LB (2007) Molar development in common chimpanzees (Pan troglodytes). J Hum Evol 52:201-216

64. Dirks W, Reid DJ, Jolly CJ, Phillips-Conroy JE, Brett FL (2002) Out of the mouths of baboons: stress, life history, and dental development in the Awash National Park hybrid zone, Ethiopia. Am J Phys Anthropol 118:239-252

65. Dean MC (2000) Progress in understanding hominoid dental development. J Anat 197:77-101

66. Beynon AD, Dean MC, Leakey MG, Reid DJ, Walker A (1998) Comparative dental development and microstructure of Proconsul teeth from Rusinga Island, Kenya. J Hum Evol 35:163-209

67. Rafferty KL, Walker A, Ruff CB, Rose MD, Andrews P (1995) Postcranial estimates of body weight in Proconsul, with a note on the distal tibia of $P$. major from Napak, Uganda. Am J Phys Anthropol 97:391-402 
68. Macho GA, Reid DJ, Leakey MG, Jablonski N, Beynon AD (1996) Climatic effects on dental development of Theropithecus oswaldi from Koobi Fora and Olorgesailie. J Hum Evol 30:57-70

69. Jungers WL, Demes B, Lamm KS (2005) New body mass estimates for extinct Malagasy lemurs based on long bone geometry. Am J Phys Anthropol 40(Suppl):125

70. Schwartz GT, Mahoney P, Godfrey LR, Cuozzo FP, Jungers WL, Randria GFN (2005) Dental development in Megaladapis edwardsi (Primates, Lemuriformes): implications for understanding life history variation in subfossil lemurs. J Hum Evol 49:702-721

71. Smith RJ, Cheverud JM (2002) Scaling of sexual dimorphism in body mass: a phylogenetic analysis of Rensch's rule in primates. Int. J Primatol 23:1095-1135

72. Ward CV, Leakey MG, Walke RA (2001) Morphology of Australopithecus anamensis from Kanapoi and Allia Bay, Kenya. J Hum Evol 41:255-368

73. Tafforeau P, Smith TM (2008) Nondestructive imaging of hominoid dental microstructure using phase contrast X-ray synchrotron microtomography. J Hum Evol 54:272-278

74. Smith TM, Reid DJ, Dean MC, Olejniczak AJ, Ferrell RJ, Martin LB (2007) New perspectives on chimpanzee molar crown development. In: Bailey S, Hublin JJ (eds) Dental palaeoanthropology. Springer, Berlin, pp 177-192

75. McHenry HM (2002) Introduction to the fossil record of human ancestry. In: Hertwig C (ed) The primate fossil record. Cambridge University Press, Cambridge, pp 401-405

76. McHenry HM (1992) Body size and proportions in early hominids. Am J Phys Anthropol 87:407-431

77. Lacruz RS, Dean MC, Ramirez-Rozzi F, Bromage TG (2009) Megadontia, striae periodicity, and patterns of enamel secretion in Plio-Pleistocene Fossil hominins. J Anat (in press)

78. Davies P, Lister AM (2001) Paleoloxodon cypriotes, the dwarf elephant of Cyprus: size and scaling comparisons with $P$. falconeri (Sicily-Malta) and mainland $P$. antiquus. In: Proceedings, 1st International Congress: The World of Elephants. Rome, pp 479-480

79. Christiansen P (2004) Body size in probiscideans, with notes on elephant metabolism. Zool J Linn Soc 140:523-549

80. Koch PL (1989) Paleobiology of late Pleistocene mastodonts and mammoths from southern Michigan and western New York. University of Michigan, Ann Arbor

81. Shipman P (1992) Body size and broken bones: preliminary interpretations of proboscidean remains. In: Fox JW, Smith CB, Wilkins KT (eds) Proboscidean and Paleoindian interactions. Baylor University Press, Waco, TX, pp 75-98

82. Fisher DC (1996) Extinctions of proboscideans in North America. In: Shoshani J, Tassy P (eds) The Proboscidea: evolution and palaeoecology of elephants and their relatives. Oxford University Press, Oxford, pp 97-315

83. Alroy J (2001) A multispecies overkill simulation of the endPleistocene megafaunal mass extinction. Science 292:1893-1896

84. Dean MC (2000) Incremental markings in enamel and dentine: what they can tell us about the way teeth grow. In: Teaford MF, Smith MM, Ferguson MWJ (eds) Development, function and evolution of teeth. Cambridge University Press, Cambridge, pp 119-130

85. Dean MC (1999) Hominoid tooth growth: using incremental lines in dentine as markers of growth in modern human and fossil primate teeth. In: Hoppa RD, FitzGerald CM (eds) Human growth in the past: studies from bones and teeth. Cambridge University Press, Cambridge, pp 111-127

86. Jungers WL (1982) Lucy's limbs: skeletal allometry and locomotion in Australopithecus afarensis. Science 297:676-678

87. Simmons AH (1999) Faunal extinction in an island society: pygmy hippopotamus hunters of Cyprus. Kluwer Academic/ Plenum, New York

88. Eltringham SK (1999) The hippos. Academic Press, London 